Ordóñez, C. 12019). Polycentric Governance in Nature-Based Solutions: Insights from Melhourne Urban Forest Managers. Landscape Architecture Frontiers, 7(3), 46-61. https.// doi.org/10.15302/J-LAF-1-020001

\section{基于自然的解决方案中的多中心治理: 墨尔本城市林业管理者的观点 POLYCENTRIC GOVERNANCE IN NATURE-BASED SOLUTIONS: INSIGHTS FROM MELBOURNE URBAN FOREST MANAGERS}

卡米罗 ·奥多内兹

澳大利亚墨尔本大学理学院生态系统和森林科学系研究员, 加拿大达尔豪斯大学资源和环境科学系博士

Camilo ORDóÑEZ

Research Fellow of School of Ecosystem and Forest Science, Faculty of Science, The University of Melbourne, Australia; PhD of Schol for Resource and Environmental Studies, Dalhousie University, Canada

*Corresponding Author

Address: 500 Yarra Boulevard, Richmond, Victoria, 3121, Australia

Email: camilo.ordonez@unimelb.edu.au

https://doi.org/10.15302/J-LAF-1-020001 收稿时间 RECEIVED DATE / 2019-05-20 中图分类号 / X37, TU984 文献标识码 / A

摘要

“基于自然的解决方案” 有助于塑造城市景 观的韧性。为了协助地方政府实施“基于自然的 解决方案”，一些新的治理模式被相继提出，引 入多中心治理过程即为其中之一。本研究以一种 典型的“基于自然的解决方案”- - 以增加城市 树木数量和提高树冠覆盖率为目的的举措和政策 为例, 聚焦于在进行城市林业相关决策时, 关键 性决策者如何协调各项行动及其优先级，以探讨 城市林业多中心治理的运作方式。本研究重点关 注多中心治理中的利益相关方, 并着重从市政管 理者的视角展开讨论, 旨在更好地厘清 “基于自 然的解决方案” 实施过程背后的社会制度。研究 所用的社会数据来源于研究者对来自澳大利亚大 墨尔本地区中的9个地方议会的19位城市林业管 理者进行的深度采访。数据分析表明, 市政管理 者所做的最重要, 同时也是受其他利益相关方影 响最大的决策包括：移除树木以让位于开发、保 留重要树木、为更新场地而植树, 以及移除老化 树木; 对这些决策影响最大的利益相关方包括非 林业市政部门、开发商、州级行为主体及居民, 而非政府绿化组织的影响较弱; 为更好地动员各 利益相关方的力量和资源, 需要协调各市政部门 之间、以及各非政府利益相关方 (尤其是开发商 和居民 ）之间的关系，并综合考虑州政府的各项 政策，同时做好公众协商。为了向应对城市化压 力的决策制定提供潜在支持, 市政管理者还需要 充分借助绿化组织的力量以保留城市现有树木, 而非仅着眼于栽植更多的树木。

\section{关键词}

城市绿化; 绿色基础设施; 自然资源管理; 社会 生态系统；多中心治理；澳大利亚

\section{ABSTRACT}

Nature-based solutions can help build resilience in urban landscapes. New governance arrangements have been suggested for assisting local governments in implementing nature-based solutions. A dominant nature-based solution initiative is the activities and policies directed at the increase of the number of trees and treecanopy coverage in a city. This study explores how polycentric governance of urban forests may operate by focusing on how key decision-makers coordinate their priorities and actions in urban forestry decisions. A stakeholder-centered view on polycentric governance is taken, specifically focused on the view of municipal managers, to develop a better understanding of the social systems behind the implementation of naturebased solutions. This was done by using social data elicited from 19 in-depth interviews with urban forest managers working in nine local councils in Greater Melbourne, Australia. The data analyses show that the most important decisions that municipal managers make, and where othe stakeholders have the most influence, relate to tree removal for developments, significant tree retention, tree planting for site renewal, and ageing trees removal. The most important stakeholders influencing these decisions include other municipal departmental units, developers state actors, and residents. Non-governmental greening groups do not play a very important role. Various types of coordination, such as the ones between municipal departments, between nongovernmental stakeholders (especially developers and residents), between state government policies, as well as public consultation, are needed to better mobilize stakeholders' influence and input. Capitalizing on greening groups that aim to retain trees in urban areas, not just planting more trees, can potentially support the current decisions made by municipal managers, which respond to urbanization pressures.

\section{KEY WORDS}

Urban Greening; Green Infrastructure; Natural Resource Management; Socio-Ecological System; Polycentric Governance; Australia 


\section{1 引言}

许多城市都采用 “基于自然的解决方案”（NBS）来塑造城市景 观的㓞性 ${ }^{[1]}$ 。NBS是指那些通过基于自然元素的干预手段来应对城市挑 战的活动、计划和政策 ${ }^{[2]}$ 。这些挑战可能包括日益严重的城市化、致密 化、生物多样性丧失和气候变化。在利用那些影响城市发展和规划的 政策工具 (如联合国发布的《新城市议程》) 时，人们意识到建立新 的治理模式来协助政府实施解决方案非常重要[3], 因此呕需对这些新治 理模式的适用条件与实施方法展开探索, 同时也需要通过研究实际案 例重新理解NBS治理的复杂性及其所需的社会制度支撑 [4- 17] 勇解NBS治 理的方法之一是探索其多中心特征，即多方主体如何共同做出决策 ${ }^{[8]}$ 。

探索NBS多中心特征的途径之一即是了解负责推行具体绿化举措的 关键性决策者如何协调其他各利益相关方的各项行动及其优先级。其 中, 旨在增加城市树木数量和提高树冠覆盖率的政策和活动是一类相 当重要的绿化举措。对于公共空间中的树木而言, 城市林业市政管理 专业人士是重要的利益相关方一一他们负责在公共空间中推行与树木 相关的举措, 并为公众共有和共享的树木和林荫空间制定策略性和实 操性决策 $[9]-[11]$ 。市政府的非林业部门、区域管理与规划部门 ${ }^{[9]}$ 、当地居 民 $^{[12]}$ 和非政府绿化组织 ${ }^{[13]}$ 等利益相关方均可以加人到城市林业管理的决 策过程中。本文对这一议题进行了探讨, 试图了解城市林业管理者如 何贯彻多中心治理模式, 并从这些模式中为落实一系列提高树冠覆盖 率和树木数量的NBS寻得支持。为实现这一目标, 研究者收集了来自澳 大利亚大墨尔本地区各地方政府城市林业管理者的一手社会数据, 并 在治理框架下进行了分析。下文将首先讨论本研究的理论基础和城市 背景。

\section{2 城市林业中的多中心治理：理论框架}

“治理”（governance ）这一概念通常是指可供不同利益相关方协 调彼此的优先级和需求的一系列制度、规则、资源和过程 ${ }^{[14][15]}$, 也被广

\section{Introduction}

Many cities implement nature-based solutions (NBS) in the desire to build resilience of urban landscapes ${ }^{[1]}$. NBS are activities, programs, and policies aimed at addressing urban challenges through interventions based on natural elements ${ }^{[2]}$. These challenges may include increased urbanization, densification, biodiversity losses, and climate change. When utilizing policy instruments that influence the development and planning of cities, such as the New Urban Agenda issued by the United Nations, the importance of developing new governance arrangements to assist governments in implementing solutions was recognized ${ }^{[3]}$. There have been calls for new research that demonstrates where and how these new governance arrangements are being implemented, and examples that can help people gain a new understanding of the complexity of NBS governance and the social systems behind $i t^{[4] \sim[7]}$. A way to understand NBS governance is to explore its polycentric character to understand how decisions are made by multiple actors ${ }^{[8]}$.

One approach to reach this purpose is to explore how key decision-makers in charge of delivering specific greening initiatives coordinate the priorities and actions with other various stakeholders. Policies and activities focused on increasing the number of trees and tree-canopy cover in a city are seen as important greening initiatives. For trees in the public realm, an important stakeholder is professional urban forest municipal managers who are in charge of implementing these initiatives in the public space, and making strategic and operational decisions about trees and treed spaces that are collectively owned and experienced $^{[9] \sim[11]}$. A variety of stakeholders may participate in the decision-making process, including other departments in local municipal governments, regional management and planning authorities $^{[9]}$, local residents ${ }^{[12]}$, and non-governmental greening groups ${ }^{[13]}$. This paper explores this topic to understand how urban forest municipal managers operate polycentric governance arrangements and find support in these arrangements to implement an NBS agenda focused on enhancing tree-canopy cover and tree numbers. To achieve this, social data were collected directly from urban forest municipal managers working for local governments in the Melbourne Metropolitan area, and analyzed according to a governance framework. The theoretical and urban context of this work is discussed below.

\section{Polycentric Governance in Urban Forests: A Theoretical Framework}

The concept of governance is generally understood as the collection of institutions, rules, resources, and processes of 


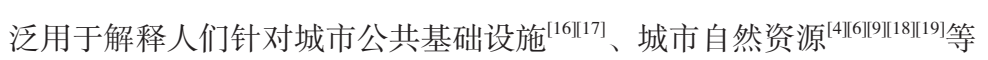
集体共有事物所做出的决策。对治理的各种解读均离不开两个基本特 点: 以多利益相关方为特征和非政府组织的参与。

治理的多利益相关方特征强调: 针对集体共有事物所做的决策必 须是多个利益相关方互动交流的结果。不同领域采用不同的语汇来描 述这一过程, 包括 “共享” “网络” “混合” “多中心”或 “马赛克 式治理模式” [5][8][20] [22]。本文选用了“多中心治理”一词, 以突显多 利益相关方这一特征。该特征对城市林业决策颇有助益一一由于城市 树木会受到包括气候、土地覆被、土地利用和管辖边界在内的各种时

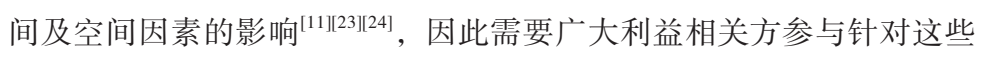
资源的决策，调和生态和社会目标之间的冲突 ${ }^{[0][25] ~[32]}$ 。

并非所有关于集体共有事物的决策都能由政府单方面制定, 非政 府方所扮演的角色也至关重要。这种 “政府之外” 的身份意味着, 在 与环境和自然资源相关的集体决策过程中, 政府只是其中一个利益相

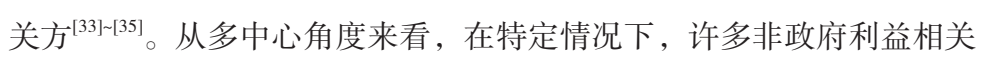
方也能够脱离政府机构独立自主地采取行动, 自下而上地实施治理策 略一一在私人组织或公私联合机构被授权管理某些城市绿地或自然资

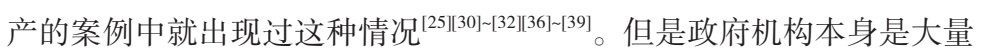
资源的持有者、规范的制定者和人民委任的管理者, 承担着回应社会 需求的职责, 因此在大多数针对公共资产的决策中, 其仍是关键的利 益相关方 ${ }^{[6][36][40] \sim 44]}$ 。例如, 在处理街道和公园等公共空间中的树木方 面, 政府就发挥着至关重要的作用一一他们通过协调相关活动和政策 来确保公众能从中获得平等的利益和价值 ${ }^{[9[25] \sim[28]}$ 。

因此, 在NBS中, 多中心治理的核心之一就是地方政府作为城市林 业的关键决策者如何协调多个 (包括非政府的) 利益相关方的力量和 资源。这些关键决策者通常是负责城市林业项目的专业人士或城市林 业管理人员，决定着栽植树木的城市公共空间的策略方向，并负责其 decision-making that allow a wide range of stakeholders to coordinate their priorities and needs ${ }^{[14][15]}$. The concept is widely used to understand decision-making in the context of what is collectively owned, including urban public infrastructure ${ }^{[16][17]}$ and city's natural resources $^{[4][6][9][18][19]}$. There are two fundamental notions to any interpretation of governance: its multi-

stakeholder character and the participation of non-governmental groups.

The multi-stakeholder notion of governance highlights that it is only through the interaction of a multiplicity of stakeholders that decisions can be made about what is collectively owned. Different fields have developed different languages to describe this process, including shared, network, hybrid, polycentric, or mosaic modes of governance $e^{[5][8][20] \sim[22]}$. In this paper, the term "polycentric governance" is used to capture this multistakeholder character. This notion is useful in urban forest decision-making. Urban trees can be affected by a wide range of temporal and spatial factors, including climate, land cover, landuse, and jurisdictional boundaries ${ }^{[11][23][24]}$. Therefore, a broad group of stakeholders need to be engaged to make decisions about these resources and deal with conflicting ecological and social objectives ${ }^{[9][25] \sim[32]}$.

Not all decisions about what is collectively owned can be made by the governments, and non-governmental agecies play an essential role. This so-called beyond-government notion implies that government is only one of the stakeholders within the collective decision-making process related to the environment and natural resources ${ }^{[33] \sim[35]}$. From a polycentric lens, many non-governmental stakeholders may have the capacity to act autonomously and independently from government institutions in specific circumstances in order to implement governance strategies in a bottom-up way. This occurs, for example, in case studies where private organizations or private-public coalitions are mandated to manage an urban green space or a natural asset $^{[25][30] \sim[32][36] \sim[39]}$. However, in most instances of decisionmaking about public assets, government institutions are still a key stakeholder, given the significant resources they owned, the norms they established, and their mandates, which are aimed at responding to the needs of society ${ }^{[6][36][40] \sim[44]}$. In the case of public trees in streets and parks, governments are vital to coordinate activities and policies to ensure that the public derives benefits and values from them equally ${ }^{[9][25] \sim[28]}$.

Therefore, a core aspect of polycentric governance in NBS is the way local governments, who play a key role in urban forest decision-making, coordinate the influence and input of multiple stakeholders, including non-governmental ones. These are usually professionals in charge of urban forestry programs, 
日常运营 ${ }^{[11] 45]}$ 。这些市政管理者负责推行以提升公共空间树冠覆盖率和 树木数量为目标的措施, 也藉此对NBS举措进行监督。因此, 了解这些 管理者如何在决策中协调其他利益相关方的力量和资源是探索NBS多中 心治理的关键。

然而, 现有基于市政管理者视角的实证文献鲜少谈及这一话题, 而大多聚焦于执行能力和战略规划等方面 ${ }^{[46]}$ —这里的执行能力是指完 成工作所需的资源，如充足的预算及人员等 ${ }^{[47]}$; 战略规划则指积极主动 的管理方式, 其衡量指标之一为是否已制定相关策略或管理计划 ${ }^{[48]}$ 。只 有部分研究基于市政管理者的视角, 探讨了在城市树种选择问题上利 益相关方对决策的影响 ${ }^{[49]}$ 。在一些特定项目, 尤其是公园改造等大规 模城市绿化项目中, 市政工程师、建筑师、城市规划师或私有土地所 有者等其他利益相关方对树种适宜性决策的影响可能超过管理者 ${ }^{[50]}$ 。不 过, 对于哪些决策需要其他利益相关方的参与, 以及如何协调他们的力 量和资源的研究仍有待进一步开展。非政府绿化组织的力量和资源 ${ }^{[36][38]}$ 、 支持者网络 ${ }^{[51]}$, 以及市民主导的绿化计划 ${ }^{[37][39]}$ 等议题均对NBS具有重要 影响; 然而, 尽管这些利益相关方能发挥重要作用, 但尚未有研究从 市政管理者的角度对他们在城市林业决策中的力量和资源进行深人探 索。理论上, 非政府主体的力量和资源能提高政府机构决策机制的适

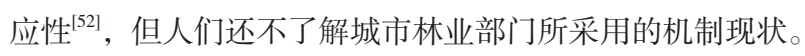

此外, 人们对于NBS和城市绿化治理方式的了解大部分来自公园等 散点式城市绿地案例 ${ }^{[4][6][18][19]}$ 。但在本文中, 城市林业的范围包括城市 中的所有树木 ${ }^{[53]}$, 并不局限于公园或一般意义上的散点式绿地。城市树 木存在于各种类型的公共和私有空间之中, 并提供具有多重尺度意义 的环境服务和社会服务一一它们既是一棵棵独立生长的树, 也共同构

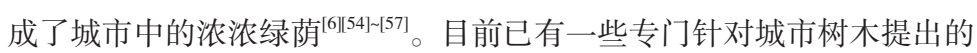
市政绿化决策, 但其对NBS多中心治理的影响才刚刚开始显现 ${ }^{[9][58]}$ 。总 or urban forest municipal managers, who make decisions about the strategic direction and day-to-day operations concerning urban public spaces with trees ${ }^{[11][45]}$. These municipal managers are the ones with the mandate of delivering the activities focused on increasing tree-canopy coverage and tree numbers in public spaces, and hence, overseeing this side of the NBS agenda. Understanding how these managers coordinate the influence and input of other stakeholders in their decisions is the key to understanding polycentric governance in NBS.

However, the existing empirical literature on the view of municipal managers provides little insights on this topic, since most of it is focused heavily on the themes of operational capacity and strategic programming ${ }^{[46]}$. Operational capacity here refers to the resources needed to get the job done, such as adequate budgets and personnel ${ }^{[47]}$. Strategic programming here refers to a pro-active approach to management, a measure of which is the existence of a strategy or a management plan ${ }^{[48]}$. Only the research on municipal manager views regarding tree selection provides some insights on how other stakeholders influence their decisions ${ }^{[49]}$. In some specific projects, particularly large-scale urban greening projects like park renewal, other stakeholders, such as municipal engineers, architects, urban planners, and private landowners, may more strongly influence the decisions about tree-species suitability, compared with managers' role $^{[50]}$. Nonetheless, more research is needed to understand which decisions require other stakeholders to participate, and how their influence and input are coordinated. Of interest in an NBS context are the influence and input of non-governmental greening groups ${ }^{[36][38]}$, advocate networks ${ }^{[51]}$, and citizen-led greening initiatives ${ }^{[37][39]}$. While these stakeholders are important, their influence and input in urban forest decision-making from the perspective of municipal managers has not been explored in depth. Theoretically, non-governmental influence and input promotes more adaptive mechanisms to decision-making in governmental institutions ${ }^{[52]}$, but people do not yet understand how this case is in urban forest municipal institutions.

Moreover, most of existing knowledge about governance of NBS and urban greening has been elicited in the context of spatially discrete urban green spaces, such as parks ${ }^{[4][6][18][19]}$. Urban forests, defined here broadly as all the trees in a city ${ }^{[53]}$, are not necessarily confined to parks or, generally, to discrete green spaces. Urban trees exist in a variety of spaces, and in both public and private areas, where they provide environmental and social services across scales: as individual trees, and as urban tree-canopy ${ }^{[6][54] \sim 57]}$. Some of the decisions about urban greening are specific to urban trees, but their implications for NBS polycentric governance are only starting to emerge ${ }^{[9][58]}$. In 
之, 城市树木治理不仅是对空间的管理, 还要考虑影响城市林业及树 木本身的生态和社会因素 ${ }^{[59]}$ 。因此, 对于城市林业中的多中心治理的理 解西待更新。

\section{3 澳大利亚的城市林业治理}

澳大利亚的许多城市已经或正在制定相关计划和策略, 以搭建地 方林业管理和治理框架 ${ }^{[60][61]}$ 。然而, 大多数文件并未阐明各利益相关方 的合作如何帮助地方政府实施城市林业相关举措 ${ }^{[62]}$ 。

大墨尔本都会区 (也称大墨尔本地区 ) 非常适合开展城市林业治 理及其中各利益相关方的协调机制等议题的研究。该地区由 32 个地方 议会组成, 拥有约 490 万居民 ${ }^{[63]}$, 人口数量居全国第二且人口增速为全 国第一 ${ }^{64]}$ 。预计到2051年，该地区的人口将达到 650 万人，届时大部分 增长集中发生在远郊地区 ${ }^{[64]}$ 。为增加城市密度、遏制城市过度扩张, 大 墨尔本地区制定了明确的应对政策 ${ }^{[65]}$ 。该地区的城市规划遵从等级化的 治理体系: 由维多利亚州政府制定城市战略规划，地方政府则负责对 当地重大事项做出决策 ${ }^{[66]}$ 。在该地区范围内的许多地方议会为提高城市 可持续性和宜居性所采取的举措中, 城市林业举措起到了重要作用; 而墨尔本市的城市林业规划尤其具有示范性作用，也是公众参与城市 林业管理的世界知名案例 ${ }^{[67]}$ ，但对于其周边城市如何推进城市林业相关 举措仍有待进一步探究。专门为大墨尔本地区制定的城市林业策略可 协调各个地方议会共同推进城市林业相关举措，体现了在更广阔的大 都会区尺度上理解城市林业治理的重要性 ${ }^{1}$ 。

大墨尔本地区城市林业的独特治理方式与其树木特征密切相关。 当地的行道树只有一小部分为本地树种 ${ }^{[68]}$, 其余大多数已被英国梧桐 (Platanus orientalis) 、英国榆树 (Ulmus procera和/或Ulmus minor) 等 欧洲落叶阔叶树种取代（图1）。于是，树种多样性问题已成为该地区 short, governing urban trees is not only about managing the space, but managing the ecological and social specificities that affect forests and trees ${ }^{[59]}$. Therefore, the understanding of polycentric governance that is specific to urban forests must be advanced.

\section{Urban Forest Governance in Australia}

Many cities across Australia have made or are currently making plans and strategies to bring structure in their management and governance of urban forests ${ }^{[60][61]}$. Yet, many of these documents are not specific about how the coordination among stakeholders can help local governments implement their urban forest agendas ${ }^{[62]}$.

The metropolitan area of Melbourne, also known as Greater Melbourne, provides a great context to study urban forest governance and its stakeholder coordination. This area comprises 32 local councils, supports approximately 4.9 million residents ${ }^{[63]}$, and has the second biggest urban population in the country but also the fastest growth ${ }^{[64]}$. It is estimated that the area's population will reach 6.5 million by 2051 with much of the growth concentrated in the outer suburbs ${ }^{[64]}$. The urban area has clear policies aimed at increasing urban densification and avoiding urban spraw ${ }^{[65]}$, whose urban planning is based on a hierarchical system of governance, with the Victorian State government setting the strategic planning direction for the city and local governments making decisions about locally significant matters ${ }^{[6]}$. Urban forest agenda is an important aspect in the urban sustainability and livability agenda advocated by many local Melbourne councils. In this term, the City of Melbourne has taken a leading role in urban forest planning and become a world-renowned case for public participation in urban forest agendas ${ }^{[67]}$, while it is still unclear that how other cities around the City of Melbourne are implementing these agendas. A metropolitan urban forest strategy development in Greater Melbourne aimed to coordinate the urban forest agenda across local councils ${ }^{\mathbb{1}}$, however, framing the importance of understanding urban forest governance in the wider metropolitan context.

The urban forests in Greater Melbourne have some important characteristics that make the governance unique. The streetscapes there have only a small percentage of indigenous species $^{[68]}$, while extic European deciduous broad-leaf trees, including London Plane trees (Platanusacerifolia) and English Elms (Ulmus procera and / or Ulmus minor), have largely replaced indigenous tree populations (Fig. 1). Subsequently, tree diversity becomes a concern for many Melbourne local government authorities ${ }^{[60][69]}$. Moreover, the urban forests in
1. 在澳大利亚墨尔本市中 心正在进行的由墨尔本 市政府主导的大学广场 市政府主导的大学广场 更新项目中，大道上老 化的英国榆树被移除前 (2018年秋, 如图1-1 所示), 刚刚移除时 (2018年10月, 如图 1-2所示) 和移除一段时 间后 (2019年3月，如 图1-3所示) 的景象。
2. 大黑尔本地区一处地块 大墨尔本地区一处地块 因房地产开发而将冠大 荫浓的树木移除, 图2- 和图2-2分别展示了树 冠移除前 (2010年) 后 (2019年) 的景象。在 大墨尔本地区, 这种情 况正越来越普遍。
1. The avenue of ageing English Elms at University Square, in downtown Melbourne, Australia, before IFall 2018, showed in Fig. 1-1), shortly after (October 2018, showed in Fig. 1-2), and long Fig. 1-2), and long after March 2019, showed in Fig. 1-3) the trees were removed for the ongoing park renewal undertaken by the City of Melbourne.
2. A site in Greater Melbourne before 12010 showed in Fig. 2-1) and after (2019, showed in after (2019, showed in Fig. 2-2) canopy trees were removed for property developmen Cases like this are becoming more and more common across the metropolitan region.



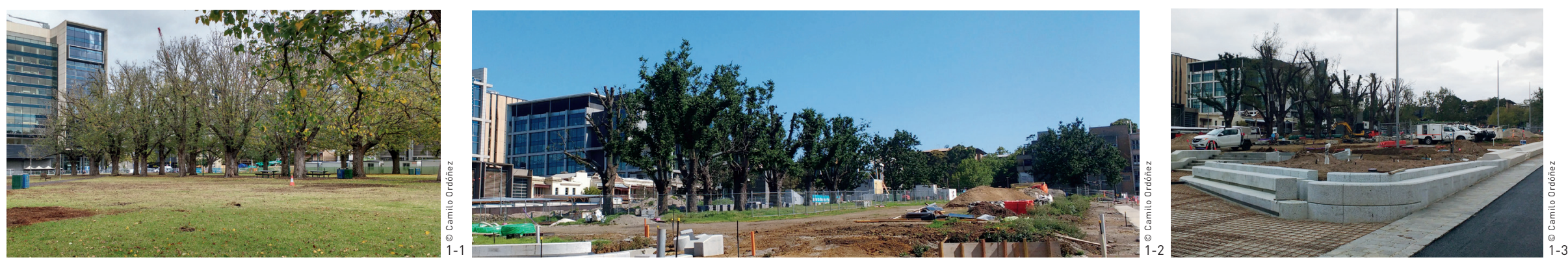

(1) 请访问“韧性墨尔 本”官方网站了解更 多信息。

(2)请访问“愿景 202020”官方网站了 解更多信息。

(1) Please visit the official website of Resilient Melbourne for more information.

for more information.
Please visit the official website of 202020 Vision for more information.
许多地方政府机构的关注焦点 ${ }^{[60[69]}$ 。此外，大墨尔本地区城市林业的 另一大特点是冠大荫浓的树木分布不均匀, 且与附近社区居民的年 龄、收人和教育水平相关 ${ }^{[70[17]}$ 。近几十年来, 随着干旱、热浪和洪水 事件愈加频发, 气候变化对于大墨尔本地区城市林业的影响也愈加

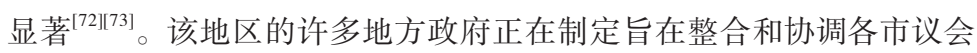
力量的大都会区城市林业战略 ${ }^{2}$ 。目前, 最亟待解决的城市林业议题包 括城市绿地的多功能性 ${ }^{[74]}$ 、城市林业治理中的公众参与 ${ }^{[67]}$, 以及在致密 化城市开发中留出足够的林地生长空间 ${ }^{[75 \mid}$ 等 (图2)。

\section{4 研究目的}

本研究旨在了解多中心治理模式在大墨尔本地区的城市林业决策 中的运作机制, 并重点关注负责实施具体绿化计划的关键决策者如何 协调其他各利益相关方的优先级及行动。本研究选取了市政管理者的 视角, 因为他们通过回应城市林业诉求来践行NBS, 是具有关键性作 用的利益相关者。研究主要围绕以下问题展开：1) 市政管理者做出的 哪些重要决策需要其他利益相关方的力量和资源? 2) 参与这些决策的 利益相关方是谁? 3 ) 这些利益相关方如何参与决策? 本研究跳脱出对 “治理” 的规范性解释，试图梳理决策制定的过程及其参与者。虽然

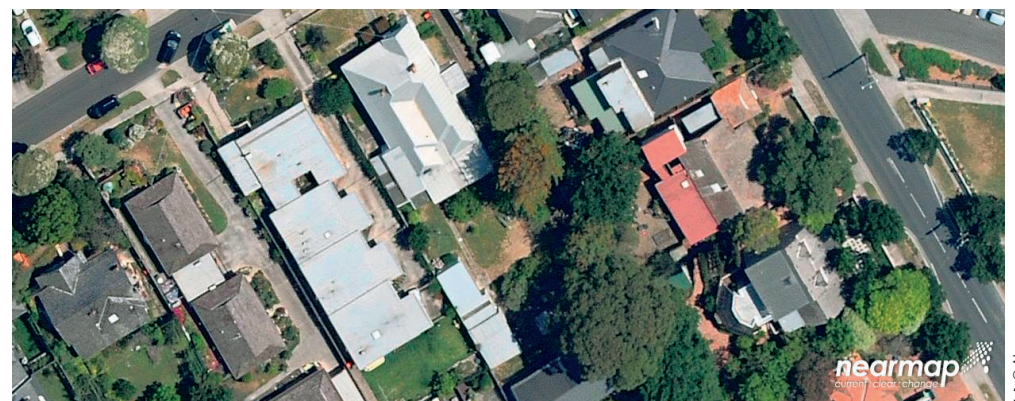

Greater Melbourne are characterized by an uneven treecanopy distribution which is related to neighborhood age, income, and education level ${ }^{[70[171]}$. Climate change represents a huge challenge for Greater Melbourne's urban forests, which has become more evident in recent decades along with the increased drought, heatwave, and flooding events ${ }^{[72[173]}$. Many local governments in the area are creating a metropolitan urban forest strategy that integrates and coordinates efforts across city councils ${ }^{2}$. Issues about the multi-functionality of urban green spaces ${ }^{[74]}$, public participation in urban forestry governance ${ }^{[67]}$, and creating enough space for growing trees due to intensified development ${ }^{[75]}$ are at the top of this urban forest agenda (Fig. 2).

\section{Study Objectives}

This study strives to understand how polycentric governance may operate in urban forest decision-making in Greater Melbourne, but focusing on how key decision-makers in charge of delivering specific greening initiatives coordinate the priorities and actions of other various stakeholders. This understanding is grounded on the perspective of municipal managers, a key stakeholder in charge of meeting the demands on urban forests as an aspect of the NBS agenda. The following research questions guided this study: 1) What important decisions made by municipal managers require the influence and input of other

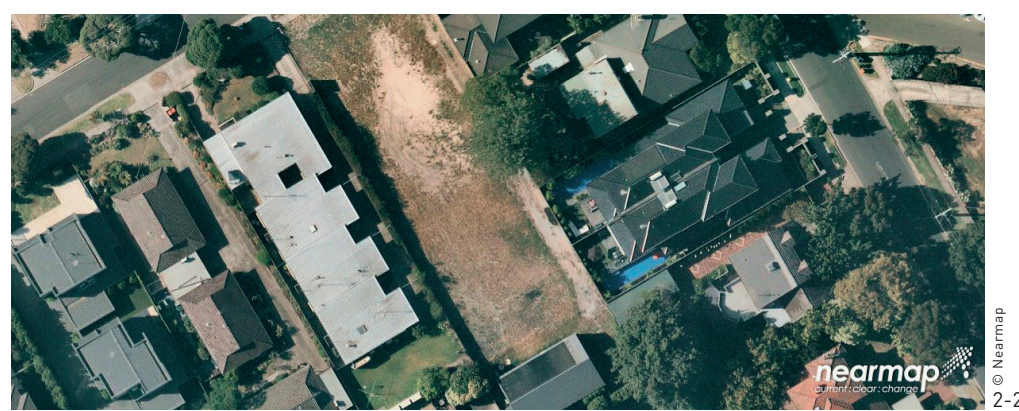


融合不同利益相关方的视角有助于扩展对治理的理解, 然而, 为了更 好地从市政管理者的视角理解决策、厘清他们在促进多中心治理时所 扮演的角色, 并探究其他利益相关方如何影响和参与决策, 本研究在 收集观点时有意排除了其他利益相关方。最后, 上述探索是基于笔者 等人提出的命题 ${ }^{[6]}$, 即通过剖析市政管理者如何通过一系列有序的步骤 对其他各利益相关方的力量和资源进行协调, 可以更加深人地理解治 理和决策过程, 进而揭示出市政管理者如何推动多中心治理, 并在其 中寻求支持以促进相关举措的实施。

\section{5 研究方法}

\section{1 分析方法与研究设计}

本研究的实证部分采用将案例定性分析 ${ }^{[76]}$ 和扎根理论 (GT) 中的 解释性程序 ${ }^{[77]}$ 相结合的方法, 从访谈中获取数据并进行分析 ${ }^{[78]}$ 。访谈 是GT研究中主要的数据收集方法 ${ }^{[77]}$, 也是对受访者观点进行权衡并 对一致性结论进行提取的首选方法。在这些访谈中, 受访者 (即城 市林业管理者) 被要求阐述需要利益相关方参与的树木管理具体决策 案例, 并就相应的决策内容详细回答具体问题 (图3)。

\section{2 数据采集}

2018年4 7月期间, 研究团队对19名市政管理者进行了深度半结构 化访谈。考虑到本文综述部分中基于城市林业管理者视角的实证研究 的样本量中位数为 20 , 此次实验的样本量符合要求 ${ }^{[4]}$ 。研究者通过向个 人发送电子邮件邀请和滚雪球抽样法, 在大墨尔本地区 32 个地方议会 的相关政府部门中尽可能多地招募了一批从事城市林业管理工作的专 stakeholders? 2) Who are the stakeholders of these decisions? and 3) How do these stakeholders participate in these decisions? This study does not rely on a normative interpretation of the concept, but rather tries to understand from the ground up how decisions are made and who participate in them. Although a wide range of stakeholders' perspectives are required for a broader understanding of governance, the study intently excludes other stakeholders since this is the only way to understand decision-making from the perspective of municipal managers, draw clearer conclusions about their role in facilitating polycentric governance, and examine how other stakeholders influence and participate in the decisions-making processes. Finally, this exploration is based on the proposition by Camilo Ordóñez et al. ${ }^{[46]}$ that a deeper understanding of governance and decision-making can be achieved by understanding the processes, to be more specific, the organizational procedures by which municipal managers coordinate the influence and input of other various stakeholders. As such, how municipal managers help facilitate polycentric governance and find support in it to implement their agenda can be revealed.

\section{Methods}

\subsection{Approach and Design}

The empirical part of this research was based on a combination of case-study qualitative research ${ }^{[76]}$ and interpretative procedures of Grounded Theory $(G T)^{[77]}$ to elicit data from interviews and analyze $\mathrm{it}^{[78]}$. Interview is the main technique of data collection in GT studies ${ }^{[77]}$, and the preferred method to negotiate and co-create knowledge grounded on the views of participants. In these interviews, participants (urban forest municipal managers) were asked for specific cases of decision-making in tree management that required stakeholders' participation. In the context of these specific decisions, they were asked to elaborate on the detailed questions (Fig. 3).

\subsection{Data Collection}

In-depth and semi-structured interviews with 19 municipal managers were completed during April to July 2018. This was an adequate sample size considering the median sample size of empirical studies focused on the view of urban forest municipal managers reviewed in this study is $20^{[46]}$. Adult professionals working in an urban forest management agency from the selected local governments of the 32 councils in Greater Melbourne were recruited as many as possible by sending personal invitations via email and using snowballing techniques. At least two people in similar capacities for each 
3. Interview protocol used in this research

\section{城市林业管理者访谈 \\ Interviews with urban forest municipal managers}

流程

．通过邮件联系受访者并用滚雪球抽样法招募更多受访者：

尽可能多地联系大墨尔本地区32个地方议会的政府机构;

在每个选出的地方政府中至少联系两位专业能力相当的受访者;

与感兴趣的受访者约定访谈时间和地点，最好是在其工作地，或在国际会议活动期间，但最终以受访者觉得舒适为准;

. 访谈开始时, 研究员简要介绍访谈内容并回答关于流程的所有问题;

研究员向受访者提供以直白语言撰写的研究声明;

. 研究员向受访者提供《知情同意书》并请受访者签字;

启动录音设备，按照如下详细问题开始谈话;

- 访谈将持续约1 小时, 并通过录音如实记录受访者的回答内容。本研究将对受访者身份保密, 访谈内容不署个人姓名及其 所属机构名称。

请您分享1 2个您做出的与公共或私人区域内树木相关的重要决策案例。可以不解释选择这些案例的原因，但请[结合具体事 例说明]。我希望您能从以下几个方面详述事情经过:

1. 为什么要保留/栽植/移除这些树? 请尽可能涵盖您能想到的所有原因或因素。

2. 在不透露或暗示任何个人信息的前提下，请问影响您决策的人、机构、组织有哪些? 如果您愿意，请简单按照影响的重要 程度对其进行排序。

3. 这些人、机构、组织如何参与到决策过程中? 您都借助了哪些方法 [请举例说明]来获得他们的支持或意见? 他们对您的决 策产生何种程度的影响?

\section{Procedure}

- Participants will be contacted via email and recruited via snowballing;

- As many local government authorities as possible will be contacted from the 32 councils in Greater Melbourne;

- At least two people in similar capacities for each selected local government will be contacted to participate;

The time and place for the interview will be arranged with the interested participant, preferably at the participant's working place, or during international conference events, but ultimately wherever the participant feels comfortable;

- At the beginning of the interview, the researcher will explain very briefly to the participant what the interview is about and answer any questions about the procedure;

The researcher will share copies of the research statement in plain expression;

- The researcher will share copies of the Consent Form and ask the participant to sign it;

The audio-recording device will be turned on and the conversation will commence following the detailed questions below;

- The interview will last approximately one hour; it will be audio-recorded, so the exact wording to answer the questions will not be lost; this research will keep the participant's identity confidential, and nothing of the conversation will be attached to their name or organization.

\section{Detailed questions}

I want you to think about one or two cases when you had to make an important decision related to trees in public or private areas. The reason does not matter, but could include [examples for illustration]. While telling me about what happened, I would like to ask you to comment on the following:

1. Why was / were the tree(s) maintained / planted / removed? Think about all the possible causes or drivers.

2. Without naming any individuals or "pointing fingers," what types of people, institutions, or organizations influenced your decision? You can briefly organize them from the most important to the least if you want.

3. How were these types of people, institutions, or organizations engaged in this case? What tools did you use [examples of tools] to get their input / views, and to what extent did these influence the decision-making about the trees? 
业人员, 每个选中的地方政府至少联系两名专业能力相当的人员, 并尽可 能安排一对一面访。最终选定的受访者和地方政府 (即样本) 的各项特 征见表 1 。研究团队首先对访谈进行录音, 再转写为英语文本。研究人类 对象所需的伦理许可由墨尔本大学批准, 且所有受访者均签署了知情同意 书。为了保护受访者隐私, 本研究不会透露样本涉及的具体地方政府。

\section{3 数据分析}

将所有音频数据和转写文本导人QSR NVivo 12 Plus定性分析软件。 按照 $\mathrm{GT}$ 解释性程序, 将编码分配给转录文本而不是强加于数据本身 (即归纳解释) ${ }^{[79]}$ (表2）。然后将这些编码聚类为分层级的组团或集 群, 且仅用被提及两次以上并具有两个以上来源 (即受访者) 的编码

表1: 在该研究中社会样本的各项特征值 Table 1: Characteristics of the social samples in this study

\begin{tabular}{|c|c|c|}
\hline \multicolumn{2}{|c|}{$\begin{array}{c}\text { 样本特征 } \\
\text { Characteristic }\end{array}$} & $\begin{array}{l}\text { 详细数据 } \\
\text { Details }\end{array}$ \\
\hline \multicolumn{2}{|l|}{$\begin{array}{l}\text { 受访人数 } \\
\text { Total number of participants }\end{array}$} & 19 \\
\hline \multicolumn{2}{|c|}{$\begin{array}{l}\text { 地方政府机构数量 } \\
\text { Total number of local government authorities }\end{array}$} & 9 \\
\hline \multicolumn{2}{|c|}{$\begin{array}{l}\text { 受访者从事城市林业工作的平均年限 } \\
\text { Participants' average working years in urban forestry }\end{array}$} & $\begin{array}{l}17.2 \text { 年 } \\
17.2 \text { years }\end{array}$ \\
\hline \multicolumn{2}{|c|}{$\begin{array}{l}\text { 受访者在地方政府工作的平均年限 } \\
\text { Participants' average working years in local government }\end{array}$} & $\begin{array}{l}8.7 \text { 年 } \\
8.7 \text { years }\end{array}$ \\
\hline \multirow{2}{*}{$\begin{array}{l}\text { 受访者的受教育水平 } \\
\text { Participants' education level }\end{array}$} & $\begin{array}{l}\text { 本科学位 } \\
\text { Bachelor's degree }\end{array}$ & 10 \\
\hline & $\begin{array}{l}\text { 研究生学位 } \\
\text { Postgraduate degree }\end{array}$ & 9 \\
\hline \multirow{3}{*}{$\begin{array}{l}\text { 地方政府机构的类型 } \\
\text { Types of local government authorities }\end{array}$} & $\begin{array}{l}\text { 内城议会 } \\
\text { Inner city councils }\end{array}$ & 3 \\
\hline & $\begin{array}{l}\text { 中城议会 } \\
\text { Mid-city councils }\end{array}$ & 4 \\
\hline & $\begin{array}{l}\text { 外城议会 } \\
\text { Outer city councils }\end{array}$ & 2 \\
\hline \multicolumn{2}{|c|}{$\begin{array}{l}\text { 研究所涉及地方政府的大致管辖人数 } \\
\text { Estimated population under the local government authorities in study }\end{array}$} & $\begin{array}{c}132.5 \text { 万 } \\
1.325 \text { million }\end{array}$ \\
\hline
\end{tabular}

注释

1. 按照维多利亚州规划局2018版规划, 大墨尔本地区由不同的地方议会组成, 其中市中心和内城议会的 管辖区域开发程度和人口密度较高, 外城议会的管辖区域人口密度较低但增速很快 构按照内城、中城和外城分类的方式为城市林业提供了一种城乡梯度, 是社会一生态科学中组织城市城 乡地区要素 ( 如建筑密度和土地利用) 的典型方式, 也有助于人们理解大墨尔本地区的生态、社会和物 乡地区要素 ( 如建筑

2. 研究所涉及地方政府的管辖人数根据澳大利亚统计局2016年人口普查数据估算得出。

NOTES

1. Greater Melbourne is comprised by different local councils, including the ones of high development and population density (center and inner city councils) and the ones of low density and high population growth (outer city councils), according to Victoria Planning Authority $(2018)^{[88]}$. The classification of city councils in terms of inner, middle, or outer characteristics responds to an urban-rural gradient len in urban forestry, as a typical way in socio-ecological science to organize the elements of urban and in urban forestry, as a typical way in socio-ecological science to organize the elements of urban and
rural areas, such as building density and land use. It is useful for understanding the linkages between rural areas, such as building density and land use. It is useful for understand
the ecological, social, and physical characteristics of Greater Melbourne ${ }^{[89]}$;

2. Population under local government authorities in this study is estimated based on 2016 Census conducted by Australia Bureau of Statistics. selected government were contacted to participate one-to-one, face-to-face interviews whenever possible. The characteristics of the participants and the local governments (i.e., the samples) are listed in Table 1. Interviews were audio-recorded and transcribed in English. Ethical approval for research with human subjects was obtained through the University of Melbourne, and informed consent was obtained from all participants. To protect the privacy of the participants, this study cannot reveal the specific local governments that were included in the samples.

\subsection{Data Analysis}

All audio and transcribed data were imported into QSR NVivo 12 Plus. Following GT interpretative procedures, codes were assigned to ideas that were recorded in the transcribed text, rather than being forced upon the data (i.e., inductive interpretation $)^{[79]}$ (Table 2). These codes were then aggregated into hierarchical groupings or clusters. Only codes with more than two references and more than two sources (i.e., interviewees) were used for aggregation. The Matrix Query function of NVivo was used to identify relationships between the codes while the Charts and Project Maps functions were used to visualize the data analyses. All interviews and analyses were carried out by the author.

\section{Results}

The results of the coding analyses are presented in terms of the frequency of mention of codes related to stakeholders (Fig. 4), and the relationship of these codes to the codes related to the types of events triggering a decision by municipal managers and management processes (Fig. 5). They show some of the most important decisions made by municipal managers, where other stakeholders participated, and the most important stakeholders who participated.

In the context of decisions related to tree removal for development projects, removal of ageing trees, tree planting for site renewal, and retention of significant trees, the most important stakeholders who participated in the decisionmaking processes were other departmental units, developers, state actors, and residents (Fig. 4, 5). Non-governmental greening groups, or groups in charge of managing particular streets, parks, or other areas with trees, only played a minor role in these decisions (Fig. 4). The results also show the required management processes for their influence and input to be integrated in the managers' decision-making processes. These processes include various types of coordinations, such 
进行聚类。随后利用NVivo的矩阵查询功能找出编码之间的关系，以及 “图表” 和 “项目地图” 功能将数据分析结果可视化。所有访谈和分 析均由笔者亲自进行。

\section{6 结果}

编码分析的结果呈现为与利益相关方有关的编码被提及的频率 （图4），以及这些编码与市政管理者的决策事件类型编码及管理过程 编码之间的关系（图5）。这些结果展示了市政管理者在其他利益相关 方参与下做出的一些最重要的决策, 以及参与决策的最重要的利益相 关方。

对于移除树木以让位于开发、移除老化树木、为更新场地而植 树, 以及保留重要树木等议题, 参与决策的最重要的利益相关方包括 非林业市政部门、开发商、州级行为主体和居民（图4，5），非政府 绿化组织和负责管理特定街道、公园或其他植树区的团体仅起次要作 用（图4）。上述结果也展示了将其他利益相关方的力量和资源融人管 理者决策的管理流程，包括协调各市政部门、协调其他利益相关方、 综合考虑州政府的各项政策，以及做好公众协商等（图5）。

\section{7 讨论与结论}

本文通过深度访谈, 在一定程度上证明了城市林业管理者如何促 进多中心治理，尤其是如何向其他利益相关方寻求支持并将他们的观 点体现在决策中。研究结果表明, 移除树木是市政管理者决策的主要 内容之一, 这也印证了近期一些综述的结论一一增加树木数量、提高 城市树冠覆盖率已成为城市林业面临的重大挑战, 且随着城市的不断 扩张, 以及致密化和整合化开发的普及, 这一挑战也愈发严峻 ${ }^{[0]}$ 。针对 这类开发，城市林业管理者的决策过程需要开发商、其他市政部门、 州级行为主体和居民的积极参与。

本研究证明了协调利益相关方在市政管理者制定决策过程中的重 要性。尽管已有研究提及协调利益相关方对于实施城市林业计划的重 要性 ${ }^{[81][82]}$, 但尚不清楚具体需要协调哪些利益相关方, 以及在什么情况 下需要进行协调。由于基于市政管理者视角的已有实证文献鲜少谈及 他们如何从其他利益相关方处寻求支持以推动城市林业相关举措的实 施, 这些问题一直未能得到充分解答 ${ }^{[46]}$, 只有一些关于树种选择的研究 涉及市政管理者在决策中如何协调其他各利益相关方的资源 ${ }^{[10[499[50]}$ 。针 对澳大利亚的已有研究表明, 众多城市林业策略都未具体说明协调利益 相关方如何有助于地方政府实施城市林业相关举措 ${ }^{[62]}$ 。本研究表明, 城 市林业管理者在决策的全过程中都需要协调非林业市政部门、开发商 和居民的资源一这些决策不仅限于树种选择, 还涉及移除、保留和 栽植树木等方面（图4)。

值得一提的是, 本研究揭示了跨部门协调在大墨尔本地区城市林 业管理者决策中的重要程度（图4，5）：市政管理者不仅仅在部门层 as the ones between departmental units, between stakeholders, between state government policies, as well as public consultation (Fig. 5).

\section{Discussion and Conclusion}

Based on in-depth interviews with urban forest municipal managers, this paper provides some evidence on how they facilitate polycentric governance, specifically, how they find support from other stakeholders and integrate their views in the decisions they make. Given the importance of tree removal events in the decisions of municipal managers, the results of this study corroborate recent reviews on the challenges of urban forestry to increase the number of trees and tree-canopy coverage in a city, particularly urbanization processes related to development projects ${ }^{[80]}$ which may include expansion of urban areas, urban densification, and urban consolidation ${ }^{[80]}$. The decision-making related to these processes are bringing developers, other municipal departmental units, state actors, and residents into the decision-making of urban forest managers.

The study demonstrates the importance of stakeholder coordination in the decision-making of municipal managers. While the coordination of stakeholders has been mentioned before as critical for the implementation of urban forestry programs ${ }^{[81][82]}$, it has remained unclear that among which stakeholders and in what contexts this coordination is needed. These have been complicated by the little insights from existing empirical literature on the view of municipal managers on how they find support from other stakeholders to implement their urban forest agenda ${ }^{[46]}$. Only studies on tree species selection show how municipal managers coordinate the input of various other stakeholders in related decisions ${ }^{[10][49][50]}$. In an Australian context, previous studies have shown that many urban forest strategies are not specific about how the coordination of stakeholders can help local governments implement their urban forest agenda ${ }^{[62]}$. This study makes it clear that municipal forest managers constantly rely on the coordination of input from other municipal departments, developers, and residents, to make decisions related to not only tree selection, but also tree removal, retention, and planting (Fig. 4).

An interesting aspect of this study is how important inter-departmental coordination is in the decision-making of urban forest managers in Greater Melbourne (Fig. 4, 5). This does not mean that the implementing actions of municipal managers are only at the departmental level, but that some of the most important decisions about public urban trees 
表2：研究中解释性编码过程的范例

Table 2: Selected examples of interpretative coding in this study

\begin{tabular}{|c|c|c|}
\hline $\begin{array}{c}\text { 范例 } \\
\text { Example }\end{array}$ & $\begin{array}{c}\text { 实录数据 } \\
\text { Verbatim data }\end{array}$ & $\begin{array}{c}\text { 编码 } \\
\text { Assigned code(s) }\end{array}$ \\
\hline 1 & $\begin{array}{l}\text { Sometimes in some streets we happen to have some landscape architect, a } \\
\text { resident, go "I want to put an Angophora Costata in there", and this is a landscape } \\
\text { architect, and we just look at him or her and go, "what are you talking about?". How } \\
\text { on earth are you going to fit a tree that size in such a small nature strip? "We want } \\
\text { big canopy for the area". It's not going to work mate. If done, residents are going to } \\
\text { come to us in } 5 \text { years time with a broken fence and asking us to pay for their fence. } \\
\text { (...) And the tree it's going to die in } 20 \text { years anyway because it's going to run out of } \\
\text { available soil space. So, it's interesting people, they don't get it }\end{array}$ & $\begin{array}{l}\text { Residents } \\
\text { Coordination other } \\
\text { stakeholders } \\
\text { Tree planting for } \\
\text { renewal }\end{array}$ \\
\hline 2 & $\begin{array}{l}\text { Yeah, sometimes we need to force the developers to replace. (...) One of the } \\
\text { components is a re-greening fee. The fee is to allow us to re-green the space. The } \\
\text { other one is the removal, getting the tree out of the ground (...). We also charge } \\
\text { them for amenity, loss of amenity (...). So this is a case by case thing, and this is } \\
\text { partly what our tree protection officers do is they work with developers to try and } \\
\text { get better outcomes (...). The ideal scenario is that whole valuation is too much } \\
\text { and they can say we're going to keep it. Because the first preference for us } \\
\text { is the tree to be retained. But if not, then the second preference is that the } \\
\text { developer will agree to design and construct in a way that will facilitate a better } \\
\text { greening outcome at the end. And this is happening more and more as we get more } \\
\text { developing applications. }\end{array}$ & $\begin{array}{l}\text { Developers } \\
\text { Coordination (with) other } \\
\text { stakeholders } \\
\text { Tree removal for } \\
\text { development }\end{array}$ \\
\hline 3 & $\begin{array}{l}\text { Electrical line clearance is going to be a real issue moving forward. Essentially } \\
\text { you got [name of state agency] who have reacted strongly to fires out in [name of } \\
\text { suburb] and have said that we need to keep lines clear at all time, and they need } \\
\text { to be a meter away from the lines at all times, or whatever the figure is. So we're } \\
\text { cutting the guts out of the trees more and the trees have less canopy on them most } \\
\text { of the time. (...) So, this is an issue with canopy coverage, and we're missing our } \\
\text { targets there. (...) They are sort of trying to say [name of state agency] that you need } \\
\text { a meter clear at all times, and it's just not necessary. So, it's a bit of an issue. And } \\
\text { moving forward it's going to cost council more money to maintain trees to those } \\
\text { levels. ( (...). Anyway. }\end{array}$ & $\begin{array}{l}\text { State actors } \\
\text { Coordination state } \\
\text { government policies }\end{array}$ \\
\hline
\end{tabular}

注释

1. (‥)代表删去的文本, 由此可以更多地关注想法本身；

2. [ ] 是为了隐去私人信息或机构名称。

NOTES

1. ( ( ) is used to indicate deleted text, so focus is given to the essence of the idea

2. [] is used to not disclose private information of individual or institutional names.

\begin{tabular}{|c|c|c|c|c|c|c|c|c|c|c|}
\hline \multirow[b]{2}{*}{$\begin{array}{l}\text { 利益相关方 } \\
\text { Stakeholders }\end{array}$} & \multicolumn{4}{|c|}{$\begin{array}{c}\text { 触发决策的事件类型 } \\
\text { Types of events triggering a decision }\end{array}$} & \multicolumn{6}{|c|}{$\begin{array}{c}\text { 管理过程 } \\
\text { Maneseses }\end{array}$} \\
\hline & $\begin{array}{c}\text { 为更新场地而植树 } \\
\text { Tree planting for } \\
\text { renewal }\end{array}$ & $\begin{array}{c}\text { 移除树木以让位于开发 } \\
\text { Tree removal for } \\
\text { development }\end{array}$ & $\begin{array}{c}\text { 保留重要树木 } \\
\text { Retention of } \\
\text { significant trees }\end{array}$ & $\begin{array}{c}\text { 移除老化树木 } \\
\text { Removal of ageing } \\
\text { trees }\end{array}$ & $\begin{array}{c}\text { 部门间协商 } \\
\text { Inter-departmental } \\
\text { coordination }\end{array}$ & $\begin{array}{c}\text { 与各市议会协商 } \\
\text { Coordination (with) } \\
\text { other councils }\end{array}$ & $\begin{array}{c}\text { 协调其他利益相关方 } \\
\text { Coordination (with) } \\
\text { other stakeholders }\end{array}$ & $\begin{array}{c}\text { 综合考虑 } \\
\text { 州政府各项政策 } \\
\text { Coordination (of) state } \\
\text { government policies }\end{array}$ & $\begin{array}{l}\text { 获取领导权 } \\
\text { 和政党支持 } \\
\text { Leadership and } \\
\text { political support }\end{array}$ & $\begin{array}{c}\text { 公共协商 } \\
\text { Public consultation }\end{array}$ \\
\hline \multicolumn{11}{|l|}{$\begin{array}{c}\text { 倡议性组织 } \\
\text { Advocacy groups }\end{array}$} \\
\hline \multicolumn{11}{|l|}{$\begin{array}{l}\text { 议会领导者 } \\
\text { Council leaders }\end{array}$} \\
\hline \multicolumn{11}{|l|}{$\begin{array}{c}\text { 市政部门 } \\
\text { Departmental units }\end{array}$} \\
\hline \multicolumn{11}{|l|}{$\begin{array}{c}\text { 开发商 } \\
\text { Developers }\end{array}$} \\
\hline \multicolumn{11}{|l|}{$\begin{array}{c}\text { 第三方专家 } \\
\text { Experts third-party }\end{array}$} \\
\hline \multicolumn{11}{|l|}{$\begin{array}{c}\text { 苗國养护者 } \\
\text { Nursery growers }\end{array}$} \\
\hline \multicolumn{11}{|l|}{$\begin{array}{c}\text { 其他议会 } \\
\text { Other councils }\end{array}$} \\
\hline \multicolumn{11}{|l|}{$\begin{array}{c}\text { 居民 } \\
\text { Residents }\end{array}$} \\
\hline \multicolumn{11}{|l|}{$\begin{array}{l}\text { 州级行为主体 } \\
\text { State actors }\end{array}$} \\
\hline \multicolumn{11}{|l|}{$\begin{array}{l}\text { 贸易商 } \\
\text { Traders }\end{array}$} \\
\hline $\begin{array}{l}\text { 从栏编码同时被提及 } \\
\% \text { of mentions w }\end{array}$ & $\begin{array}{l}(\%) \\
\text { e code }\end{array}$ & & $50 \sim 74$ & & $25 \sim 49$ & & $1 \sim 24$ & & 狓提及 & \\
\hline
\end{tabular}


Frequency of mention of codes assigned to the themes of stakeholders, based on data elicited from urban forest municipal managers in Greater Melbourne.

Relationship of codes assigned to the themes of stakeholders, types of events, and management processes, in terms of the frequency of mention of a code when the other one is present.
面采取行动，也在关于城区公共树木的一些最重要的决策上与其他市 政部门共同协作。协作的原因有二：其一是决策的制定背景。大部分 决策都与树木的去留问题相关（图5），这意味着很多情况下直接做出 决定的可能不是城市林业管理者，而是其他市政部门; 其二是更广泛 的制度背景。萨拉 - K - 明塞等 ${ }^{[45}$ 对埃莉诺 - 奥斯特罗姆的制度化治理 框架 ${ }^{[20]}$ 进行了改进, 使其适用于城市林业领域。此框架下的地方政府并 非是一个统一协调政治、社会和经济事务的架构清晰的集成机构，而 是一个较为松散、无固定优先层级的多机构组织。许多地方政府试图 通过让众多部门参与制定城市林业战略，来解决城市林业治理中协作 缺失的问题 ${ }^{[83]}$, 然而, 若想长期推行这些战略, 这些部门的积极协作同 样必不可少——这不仅体现在总体战略的制定过程中, 也体现在与树 木去留问题有关的决策细节上。随着各城市开始制定大都市区尺度的 战略和政策，城市林业治理中的问题也愈加凸显。在这一更广阔的背 景下, 制定促进市政部门和其他利益相关方间协调的明确战略, 将辅 助市政管理者制定决策，从而推动城市发展。

虽然部分文献提到了非政府绿化组织 ${ }^{[36][38]}$ 、支持者网络 ${ }^{[5]}$ 和市民主 导计划 ${ }^{[37][39]}$ 参与NBS决策的重要性，但本研究发现，在市政管理者做出 某些重要决策时, 这些群体表现并不活跃, 特别是在城市开发项目中 的树木移除及重要树木保留的相关决策方面（图5)。尽管市政管理者 会在公众协商环节积极征求居民意见，并与其他市政部门及开发商协 商以推进相关举措, 但他们并未感受到来自这些绿化组织或团体的影 响, 也未向其寻求支持。布艾斯 - 阿尔扬等 ${ }^{[5][39]}$ 认为, 这些组织未能参 与决策的原因之一在于他们更偏向参与新增性计划, 如在城市中植树 或建造新的社区花园等, 而非那些决定现有树木去留的计划。墨尔本 市是公众参与城市林业管理的一个范例 ${ }^{[67]}$ ，但这种参与主要集中在制定 地方城市林业分区管辖规划方面，很少涉及树木去留问题的决策。不 require the coordination with other departmental units within a municipality. This has several reasons: First, the context of decision-making processes. Most of these decisions are triggered by tree removal or retention events (Fig. 5), which may mean that a lot of decisions related to these events are probably not made directly by urban forest minicipal managers but by other departmental units in the municipal institution. Second, a broader institutional context. Using Elinor Ostrom's institutional governance framework ${ }^{[20]}$, adapted by Sarah K. Mincey et al. ${ }^{[45]}$ for an urban forest context, it can be argued that local governments are not monolithic institutions, that is, well-structured collectives which coordinate political, social, and economic actions, but rather diverse institutions where priorities are not well aligned. Many municipalities try to address the lack of coordination in urban forest governance by engaging many institutional departments in the development of urban forest strategies ${ }^{[83]}$. However, the long-term implementation of these strategies still depends on the active coordination of these departments, which are reflected in the minutiae of decisions related to tree removal and retention, and not just on the creation of an over-arching strategy. The weaknesses in urban forest governance eventually amplifies as cities work toward developing metropolitan-wide strategies and policies. In these broader contexts, cities will be benefited from developing a clear strategy aimed at improving the coordination of municipal departments and stakeholders to aid the decision-making process of municipal managers.

While some literatures mention the importance of integrating non-governmental greening groups ${ }^{[36][38]}$, advocate networks ${ }^{[51]}$, and citizen-led initiatives ${ }^{[37][39]}$ within the decisionmaking of NBS, this study shows that these groups are not active in the context of the most important events that trigger municipal manager decisions, specially tree removals due to development projects and retentions of significant trees (Fig. 5). While municipal managers actively seek the input of residents via public consultation processes and negotiate with other municipal departments and developers to implement their agenda, they do not feel influenced by or seek to find support from these greening groups or collectives. One of the reasons that these groups may not be engaged in these decisions was suggested by Buijs Arjen et al. ${ }^{[5][39]}$ that these groups prefer additive initiatives, such as planting urban trees, or creating new community gardens, instead of initiatives focused on the protection or retention of what is already there. A good example of this is the City of Melbourne, which is a renowned case of public participation in urban forestry ${ }^{[67]}$, but this participation has occurred primarily in the context of developing local 
可否认的是, 要顺利实施城市林业相关举措, 地方政府必须与各利益 相关方建立密切关系 ${ }^{[251361383}$, 这样一来, 市政管理者才能动员这些组织 和市民将他们的资源也同样投入树木保留和保护计划中, 以有效应对 在城市化压力下，管理者越来越难以保留公共空间中的树木的问题。 未来的研究需要对这一问题展开更深人的探讨。

本研究并未特别要求受访者阐述在哪些情况下会让非政府利益相 关方参与决策, 而是旨在更广泛地了解如何制定决策以及谁参与了决 策, 而非事先预设有非政府主体参与其中。不过, 市政管理者显然必 须具备某些关键能力, 尤其是更广的人脉和更强的沟通能力, 才能让 非政府利益相关方真正参与进来。有人提出推动城市林业治理的方法 之一是为社区赋权 ${ }^{[9][11] \sim[13]}$, 但赋权并不意味着社区管理机制会自动形 成, 而是需要所有能够影响城市林业和树木情况的人士共同努力 ${ }^{[39][51]}$ 。 从市政管理者角度看，协调利益相关方会使NBS的治理过程更加复杂。 尽管为城市林业部门提供更多资源并不会降低管理者协调利益相关方 的难度, 但由于完成协调工作的要求较高, 这种投人仍然十分必要。 目前, 大部分有关非政府主体在城市林业治理中的角色的研究都是基 于散点状的城市绿地 (如社区组织共同管理的公园等) 治理 ${ }^{[4] 6][18][19]}$, 对于非政府组织如何参与公共和私人空间、正式和非正式空间中的树 木决策的系统性治理, 仍未加以明确。未来仍需要进一步的研究, 以 了解这些关键能力是什么、应运用在何处, 以及如何有效促进 NBS 的 系统性实施。

尽管NBS以及其中的城市林业相关举措有助于重塑城市韧性（包 括应对气候变化等环境挑战的韧性 ) ${ }^{[1][2][7]}$, 但目前对于社会系统韧性 的关注仍相对不足。在社会一生态韧性视角下，如何基于城市自然 资源 ${ }^{[4][6][9][18][19]}$ 等集体共有事物实现自然与社会系统之间，以及不同

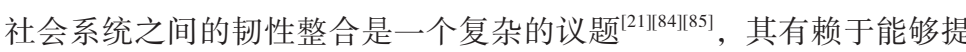
供充足的知识、资源和技能支持的社区管理机制的介人。以应对气候 urban-forest precinct plans, while little in tree retention. It is undeniable that to successfully implement an urban forest agenda, local governments must successfully engage with the stakeholders ${ }^{[25][36][38]}$, so that the municipal managers could capitalize on the input of these groups and other engaged citizens in the context of retention and protection, not just planting initiatives. This is important because retention and protection initiatives are the ways urban forest municipal managers respond to the urbanization pressures that make it increasingly difficult for managers to retain trees in public space. Future research should shed some light on this issue.

Participants in this study were not specifically asked to elucidate on the opportunities for involving non-governmental stakeholders in their decisions; rather, research questions were aimed at understanding more broadly how decisions are made and who participate in the decision, instead of making assumptions about the participation of non-governments. Yet, it is clear that municipal managers need some key capacities to involve non-governmental stakeholders, specifically, more resources in personnel and communication capacities. Enabling community stewardship has been suggested to advance the governance of urban forests ${ }^{[9][11] \sim[13]}$. However, community stewardship does not happen automatically, but needs a concerted effort among all of those involved in influencing what happens to urban forests and trees ${ }^{[39][51]}$. Stakeholder coordination can add complexities to governing NBS from the perspective of municipal managers. While placing more resources on urban forest departments will not make it easier for managers to coordinate stakeholders, the act of coordination itself demands a better capacity. With a lot of knowledge about the role of non-governments in urban forest governance, which is specifically from the lens of spatially discrete urban green spaces, such as parks co-managed by communitybased groups ${ }^{[4][6][18][19]}$, it is still unclear how non-governmental groups participate in the systemic governance of urban trees in both public and private, formal and informal spaces. Further research is needed to understand what these key capacities are, where they exist, and how they can effectively help implement NBS systematically.

While NBS, and the urban forest agenda within it, have been promoted as an enabler of urban resilience, including resilience to environmental challenges such as climate change adaptation $^{[1][2][7]}$, less attention is placed on the resilience of social systems. In the realm of socio-ecological resilience, a complex task that strives to integrate the resilience of natural and social systems, and the resilience of connected social systems in the context of what is collectively owned ${ }^{[21][84][85]}$, including urban natural resources ${ }^{[4][6][9][18][19]}$, requires community 
变化为例, 虽然城市森林能提高城市对气候变化的适应能力, 但从树 种自身对气候变化的适应能力以及树木与野生动植物的联系 ${ }^{[86]}$ 等与生 态系统脆弱性相关的角度来看, 城市树木仍缺乏足够的韧性来应对气 候变化。不过, 这种脆弱性有其社会成因, 因为治理的方方面面的因 素一一如协调利益相关方、资金、人员配置、社区支持、项目监督和 知识的缺乏等——都会影响城市林业的脆弱性 ${ }^{[87]}$ 。如果不能利用知识、 资源和技术来优化城市林业治理背后脆弱的社会系统，城市林业应对 气候变化的韧性仍将存在重大缺陷。

本研究呈现了多中心治理在大墨尔本地区城市林业中的运行情 况, 但并未明确指出该地区的城市林业是以多中心方式进行治理的。研 究的主要局限在于仅研究了政府和市政管理者的单一视角。诚然, 只有 从多个利益相关方的角度展开研究才能对多中心治理形成全面的理解。 传统的城市绿化治理文献大多关注在纯私人主导或公私合作的直接管 理模式下, 非政府行为主体如何落实城市林业管理举措 ${ }^{[30] \sim[32][36] \sim[39]}$; 但 必须承认, 作为这些行动的推动者和参与者, 治理机构和政府专业人 土的观点同样十分重要。此外, 除了栽植更多的树木, 市政管理者还 需要充分借助绿化组织的力量保留城市中已有的树木, 这将更好地为 制定应对城市化压力的决策提供支持。最后, 政府专业人士的使命是 保护、保留和改善城市绿地和城市林木, 确保人们可以从中获得广泛 的利益和价值。将这些关键决策者联合起来, 了解他们的关注点和所 面临的挑战, 对理解如何在NBS背景下开展多中心治理至关重要。LAF

致谢

作者感谢巴拉瑞特市、休姆市、墨尔本市和莫兰德市对研究提供的支持, 并特别感谢卡拉夫 $\cdot G \cdot$ 斯瑞尔 福博士、德芙 $\cdot$ 肯德尔博士、迪耶特 $\cdot F \cdot$ 霍储利博士、梅兰妮・达文博士、理查德・A 富勒博士、罗德 尼 $\cdot$ 凡 德・雷博士和斯蒂芬 $\cdot J \cdot$ 莱福斯利博士的指导。 stewardship with adequate capacities, including knowledge, resources, and skills. An example of this can be given in the context of climate change. While urban forests can facilitate climate adaptation of cities, urban trees are still vulnerable, in terms of the suitability of tree species to future climate and tree-wildlife connections ${ }^{[86]}$, among other ecosystem vulnerability issues. Yet, this vulnerability also has its meaning in a social context. Aspects of governance like coordination of stakeholders, funding, staffing, community support, monitoring programs, and lack of knowledge, can all affect urban forest vulnerability $^{[87]}$. Without addressing the vulnerability of this social system behind urban forest governance, in terms of knowledge, resources, and skills, the climate resilience of urban forests will be challenged.

This study has provided some evidence on how polycentric governance operates in the urban forests of Greater Melbourne, yet it does not specifically claim that the urban forests in this area are governed in a polycentric manner. An important limitation of this work is its government's and municipal managers' focus. It is recognized here that a broader understanding of polycentric governance can only be elucidated by studying the perspectives of multiple stakeholders. Conventional urban greening governance literature has focused more on the role of non-governmental initiatives in specific contexts where private organizations or private-public coalitions manage urban forests more directly ${ }^{[30] \sim[32][36] \sim[39]}$. However, in doing this work, it remains important to understand the perspective of governance institutions and government professionals who facilitate and participate in these arrangements. Building from the discussion above, it is also important to understand how municipal governments capitalize on greening groups that focus on the retention of trees, rather than just the planting of trees, as these initiatives can better support the decisions in response to urbanization pressures. Ultimately, the mandate of these government professionals is to protect, retain, and enhance urban green spaces and urban forests, and make sure that people can derive a wide range of benefits and values from them. Engaging these key decision-makers, as well as understanding their concerns and challenges, is fundamental to understand how polycentric governance is implemented in an NBS context. LAF

\section{ACKNOWLEDGEMENTS}

The author thanks the City of Ballarat, City of Hume, City of Melbourne, and City of Moreland for their support. Special thanks to Drs. Caragh G. Threlfall, Dave Kendal, Dieter F. Hochuli, Melanie Davern, Richard A. Fuller, Rodney van der Ree, and Stephen J. Livesley for their guidance. 
[1] Kabisch, N., Frantzeskaki, N. Pauleit, S., Naumann, S., Davis, M., Artmann, M., ... Bonn, A. (2016). Nature-based solutions to climate change mitigation and adaptation in urban areas Perspectives on indicators, knowledge gaps, barriers, and opportunities for action. Ecology and Society, 21(2), 39. http:// dx.doi.org/10.5751/ES-08373-210239

[2] Nesshöver, C., Assmuth, T., Irvine, K. N., Rusch, G. M., Waylen, K. A., Delbaere, B., ... Wittmer, H. (2017). The science, policy a., Delbiere $B$, Whed and practice of nature-based solutions: An interdisciplinary perspective. Science of the Total Environment, [579],

[3] UN-HABITAT. (2018). The new urban agenda. UN, Nairobi, Kenya. Retrieved from http://habitat3.org/the-new-urbanagenda/

[4] Frantzeskaki, N., Kabisch, N., \& McPhearson, T. (2016). Advancing urban environmental governance: Understanding theories, practices and processes shaping urban sustainability and resilience. Environmental Science \& Policy, (62), 1-6. https://doi.org/10.1016/j.envsci.2016.05.008

[5] Buijs, A. E., Mattijssen, T. J. M., Van Der Jagt, A. P. N. Ambrose-Oji, B., Andersson, E., Elands, B. H., \& Stee Møller, M. (2016). Active citizenship for urban green infrastructure: Fostering the diversity and dynamics of citizen contributions through mosaic governance. Current Opinion in Environmental Sustainability, (22), 1-6. https://doi. org/10.1016/j. cosust.2017.01.002

[6] Green, 0. O., Garmestani, A. S., Albro, S. Ban, N. C., Berland, A., Burkman, C. E., ... Shuster, W. D. (2016). Adaptive governance to promote ecosystem services in urban green space. Urban Ecosystems, 19(1), 77-93. https://doi. org/10.1007/s11252-015-0476-2

[7] Faivre, N., Fritz, M., Freitas, T., De Boissezon, B., \& Vandewoestijne, S. (2017). Nature-Based Solutions in the EU: Innovating with Nature to Address Social, Economic and Environmental Challenges. Environmental Research, (159), 509-518.

[8] Ostrom, E. (2010). Beyond markets and states: Polycentric Governance of Complex Economic Systems. The American Economic Review, 100(3), 641-672. doi:10.1257/aer.100.3.641

[9] Lawrence, A., De Vreese, R., Johnston, M., Konijnendijk van den Bosch, C. C., \& Sanesi, G. (2013). Urban forest governance: Towards a framework for comparing approaches. Urban Forestry \& Urban Greening, 12(4), 464-473. https://doi. org/10.1016/j.ufug.2013.05.002

[10] Kirkpatrick, J. B., Davison, A. \& Harwood, A. (2013). How tree professionals perceive trees and conflicts about trees in Australia's urban forest. Landscape and Urban Planning. 119(Supplement C), 124-130. https://doi.org/10.1016/ j.landurbplan.2013.07.009

[11] Roman, L. A., Pearsall, H., Eisenman, T. S., Conway, T. M., Fahey, R. T., Landry, S., ... Staudhammer, C. (2018). Human and biophysical legacies shape contemporary urban forests: A literature synthesis. Urban Forestry \& Urban Greening, (31), 157-168. https://doi.org/10.1016/j.ufug. 2018.03.004

[12] Daniel, C., Morrison, T. H., \& Phinn, S. (2016). The governance of private residential land in cities and spatial effects on tree cover. Environmental Science \& Policy, (62), 79-89. https://do org/10.1016/j.envsci.2016.01.015

[13] Conway, T. M., Shakeel, T., \& Atallah, J. (2011). Community groups and urban forestry activity: Drivers of uneven canopy cover?. Landscape and Urban Planning, 101(4), 321-329. https://doi.org/10.1016/j.landurbplan.2011.02.037
[14] Lemos, M. C., \& Agrawal, A. (2006). Environmental governance. Annual Review of Environment and Resources, (31), 297-325. https://doi.org/10.1146/annurev. energy.31.042605.135621

[15] Delmas, M. A., \& Young, O. A. (Eds.) (2009). Governance for the environment: New perspectives. Cambridge: Cambridg University Press.

[16] Rhodes, R. A. W. (1996). The New Governance: Governing without Government. Political Studies, 44(4), 652-667. https:// doi.org/10.1111/j.1467-9248.1996.tb01747.x

[17] Stoker, G. (1998). Governance as theory: Five propositions. International Social Science Journal, 50(155), 17-28. https:// doi.org/10.1111/1468-2451.00106

[18] Forgione, H. M., Pregitzer, C. C., Charlop-Powers, S., \& Gunther, B. (2016). Advancing urban ecosystem governance in New York City: Shifting towards a unified perspective for conservation management. Environmental Science \& Policy (62), 127-132. https://doi.org/10.1016/j.envsci.2016.02.012

[19] Foo, K., McCarthy, J., \& Bebbington, A. (2018). Activating landscape ecology: A governance framework for designin-science. Landscape Ecology, 33(5), 675-689. https://doi. org/10.1007/s10980-018-0630-3

[20] Ostrom, E., Burger, J., Field, C. B., Norgaard, R. B., \& Policansky, D. (1999). Revisiting the Commons: Local Lessons, Global Challenges. Science, 284(5412), 278-282. doi:10.1126/ science. 284.5412 .278

[21] Folke, C., Hahn, T., Olsson, P., \& Norberg, J. (2005). Adaptive governance of social-ecological systems. Annual Review governance of socia-ecological systems. Annual Review
of Environment and Resources, (30), 441-473, https://do org/10.1146/annurev.energy.30.050504.144511

[22] Arnouts, R., Van Der Zouwen, M., \& Arts, B. (2012). Analyzing governance modes and shifts - Governance arrangements in Dutch nature policy. Forest Policy and Economics, (16), 43-50.

[23] Rowntree, R. A. (1984). Ecology of the urban forest Introduction to part I. Urban Ecology, 8(1-2), 1-11. https://doi. org/10.1016/0304-4009(84)90003-2

[24] Nowak, D. J. (1993). Historical vegetation change in Oakland and its implications for urban forest management. Journal of Arboriculture, 19(5), 313-319.

[25] Sipilä, M., \& Tyrväinen, L. (2005). Evaluation of collaborative urban forest planning in Helsinki, Finland. Urban Forestry \& Urban Greening, 4(1), 1-12. https://doi. org/10.1016/j.ufug.2005.06.002

[26] Janse, G., \& Konijnendijk, C. C. (2007). Communication between science, policy and citizens in public participation between science, policy and cilizens in public paticipation in urban forestry - Experiences from the Neighbourhoods
project. Urban Forestry \& Urban Greening, 6(1), 23-40. https:// project. Urban Forestry \& Urban $G$
doi.org/10.1016/j.ufug.2006.09.005

[27] Pincetl, S. (2010). Implementing Municipal Tree Planting: Los Angeles Million-Tree Initiative. Environmental Management, 45(2), 227-238. doi:10.1007/s00267-009-9412-7

[28] Molin, J. F., \& Konijnendijk van den Bosch, C. C. (2014). Between Big Ideas and Daily Realities - The roles and perspectives of Danish municipal green space managers on public involvement in green space maintenance. Urban Forestry \& Urban Greening, 13(3), 553-561. https://doi. org/10.1016/j.ufug.2014.03.006

[29] Duinker, P. N., Steenberg, J., Ordóñez, C., Cushing, S., \& Perfitt, K. R. (2015). Governance and Urban Forests in Canada: Roles of Non-Government Organisations. In M. Johnson \& G. Percival (Eds.), Trees, People, and the Built Environment II Conference Proceedings (pp. 151-159). Edinburgh: Institute of

\section{Chartered Foresters}

[30] Fors, H. Molin, J. F., Murphy, M. A., \& Van Den Bosch, C. K. (2015). User participation in urban green spaces - for the people or the parks?. Urban Forestry \& Urban Greening, 14(3), 722-734. https://doi.org/10.1016/j.ufug.2015.05.007

[31] Ugolini, F., Massetti, L., Sanesi, G., \& Pearlmutter, D. (2015). Knowledge transfer between stakeholders in the field of urban forestry and green infrastructure: Results of a European survey. Land Use Policy, (49), 338-365. https://doi. org/10.1016/j.landusepol.2015.08.019

[32] Varuzzo, A., \& Harvey, D. C. (2017). Disproportionalities in the urban forest: Analyzing the role of stewardship agencies in dictating the distribution of an urban environmental resource. Landscape and Urban Planning, (167), 232-239. https://doi. org/10.1016/j.landurbplan.2017.06.006

[33] Kleinschmit, D., Böcher, M., \& Giessen, L. (2009). Discourse and expertise in forest and environmental governance $-A n$ overview. Forest Policy and Economics, 11(5-6) 309-312. overview. Forest Policy and Economics, $11 / 5-6 / .3$
https://doi.org/10.1016/j.forpol.2009.08.001

[34] Lockwood, M., Davidson, J., Curtis, A., Stratford, E., \& Griffith, R. (2010). Governance Principles for Natural Resource Management. Society \& Natural Resources, 23(10), 986-1001. https://doi.org/10.1080/08941920802178214

[35] Bell, S., \& Hindmoor, A. (2012). Governance without government? The case of the forest stewardship council. Public Administration, 90(1), 144-159. https://doi.org/10.1111/ j.1467-9299.2011.01954.x

[36] Newig, J., Günther, D., \& Pahl-Wostl, C. (2010). Synapses in the Network: Learning in Governance Networks in the Context of Environmental Management. Ecology and Society, 15(4), 24. Retrieved from http://www.ecologyandsociety.org/vol15/iss4/ art24/

[37] Dennis, M., \& James, P. (2016). User participation in urban green commons: Exploring the links between access, voluntarism, biodiversity and well being. Urban Forestry \& Urban Greening, (15), 22-31. https://doi.org/10.1016/ j.ufug. 2015.11.009

[38] Meerow, S., \& Newell, J. P. (2017). Spatial planning for multifunctional green infrastructure: Growing resilience in Detroit. Landscape and Urban Planning, (159), 62-75. https:// doi.org/10.1016/j.landurbplan.2016.10.005

[39] Buijs, A., Hansen, R., Van Der Jagt, S., Ambrose-0ji, B., Elands, B., Lorance-Rall, E., ... Steen-Møller, M. (2019). Mosaic governance for urban green infrastructure: Upscaling active citizenship from a local government perspective. Urban Forestry \& Urban Greening, (40), 53-62. https://doi. org/10.1016/j.ufug.2018.06.011

[40] Davies, J. S. (2003). Partnerships versus Regimes: Why Regime Theory Cannot Explain Urban Coalitions in the UK. Journal of Urban Affairs, 25(3), 253-270. https://doi. org/10.1111/1467-9906.00164

[41] Bulkeley, H., \& Betsill, M. (2005). Rethinking Sustainable Cities: Multilevel Governance and the "Urban" Politics of Climate Change. Environmental Politics, 14(1), 42-63. https:// doi.org/10.1080/0964401042000310178

[42] Borgström, S. T., Elmqvist, T., Angelstam, P., \& AlfsenNorodom, C. (2006). Scale mismatches in management of urban landscapes. Ecology and Society, 11(2), 437-466. doi:10.5751/ES-01819-110216

[43] Cars, G., Healey, P., Madanipour, A., \& De Magalhaes, C. (Eds.) (2002). Urban Governance, Institutional Capacity and Social Milieux. London: Routledge. 
[44] Borgström, S. (2019). Balancing diversity and connectivity in multi-level governance settings for urban transformative capacity. Ambio, 48(5), 463-477. https://doi.org/10.1007/ s13280-018-01142-1

[45] Mincey, S. K., Hutten, M., Fischer, B. C., Evans, T. P., Stewart, S. I., \& Vogt, J. M. (2013). Structuring institutional analysis for urban ecosystems: A key to sustainable urban forest management. Urban Ecosystems, 16(3), 553-571. https://doi. org/10.1007/s11252-013-0286-3

[46] Ordóñez, C. Threlfall, C. G. Kendal, D., Hochuli, D. F. Davern, M., Fuller, R. A., ... Livesley, S. (2019). Urban forest governance and decision-making: A systematic review and synthesis of the perspectives of municipal managers. Landscape \& Urban Planning, (189), 166-180. https://doi. org/10.1016/j.landurbplan.2019.04.020

[47] Driscoll, A. N., Ries, P. D., Tilt, J. H., \& Ganio, L. M. (2015). Needs and barriers to expanding urban forestry programs: An assessment of community officials and program managers in the Portland - Vancouver metropolitan region. Urban Forestry \& Urban Greening, 14(1), 48-55. https://doi. Urban Forestry \& Urban Green
org/10.1016/j.ufug.2014.11.004

[48] Davies, H. J., Doick, K. J., Hudson, M. D., \& Schreckenberg, K. (2017). Challenges for tree officers to enhance the provision of regulating ecosystem services from urban forests. Environmental Research, (156), 97-107. https://doi. org/10.1016/j.envres.2017.03.020

[49] Roy, S., Davison, A., \& Ostberg, J. (2017). Pragmatic factor outweigh ecosystem service goals in street tree selection and planting in South-East Queensland cities. Urban Forestry \& Urban Greening, (21), 166-174. https://doi. org/10.1016/j.ufug.2016.12.003

[50] Conway, T. M., \& Van Der Vecht, J. (2015). Growing a diverse urban forest: Species selection decisions by practitioners planting and supplying trees. Landscape and Urban Planning (138), 1-10. https://doi.org/10.1016/j.landurbplan.2015.01.007

[51] Connolly, J. J., Svendsen, E. S., Fisher, D. R., \& Campbell, L. K. (2013). Organizing urban ecosystem services through L. K. (2013). Organizing urban ecosystem services through
environmental stewardship governance in New York City. Landscape and Urban Planning, 109(1), 76-84. https://doi. org/10.1016/j.landurbplan.2012.07.001

[52] Berkes, F. (2010). Devolution of environment and resources governance: Trends and future. Environmental Conservation, 37(4), 489-500. https://doi.org/10.1017/S037689291000072X

[53] Konijnendijk, C. C., Ricard, R. M., Kenney, A., \& Randrup, T. B. (2006). Defining urban forestry - A comparative perspective of North America and Europe. Urban Forestry \& Urban Greening, 4[3-4], 93-103. https://doi org/10.1016/j.ufug.2005.11.003

[54] Nowak, D. J., Crane, D. E., Stevens, J. C., Hoehn, R. E., Walton, J. T., \& Bond, J. (2008). A ground-based method of assessing urban forest structure and ecosystem services. Arboriculture \& Urban Forestry, 34(6), 347-358.

[55] Bowler, D. E., Buyung-Ali, L., Knight, T. M., \& Pullin, A. S. (2010). Urban greening to cool towns and cities: A systematic review of the empirical evidence. Landscape and Systematic review of the empirical evidence. Landscape and Urban Planning, 97(3), 147-

[56] Dobbs, C., Escobedo, F. J., \& Zipperer, W. C. (2011). A framework for developing urban forest ecosystem services and goods indicators. Landscape and Urban Planning, 99/34), 196-206. https://doi.org/10.1016/j.landurbplan.2010.11.004 [57] Livesley, S. J., McPherson, G. M., \& Calfapietra, C. (2016).
The Urban Forest and Ecosystem Services: Impacts on Urba Water, Heat, and Pollution Cycles at the Tree, Street, and City Scale. Journal of Environmental Quality, 45(1), 119-124. doi:10.2134/jeq2015.11.0567

[58] Van Der Jagt, A. P. N., \& Lawrence, A. (2019). Local government and urban forest governance: Insights from scotland. Scandinavian Journal of Forest Research, 34(1), 5366. https://doi.org/10.1080/02827581.2018.1532018

[59] Steenberg, J. W. N., Duinker, P. N., \& Nitoslawski, S. A. (2019). Ecosystem-based management revisited: Updating the concepts for urban forests. Landscape and Updating the concepts for urban forests. Landscape an Urban Planning, (186), 24-35.

[60] City of Melbourne. (2012). Urban forest strategy - Making a great city greener 2012-2032. Retrieved from https://www. melbourne.vic.gov.au/SiteCollectionDocuments/urban-foreststrategy.pdf.

[61] City of Sydney. (2013]. Urban Forest Strategy. Retrieved from https://www.cityofsydney.nsw.gov.au/_data/assets/pdf file/0003/132249/Urban-Forest-Strategy-Adopted-Feb-2013. pdf

[62] Phelan, K., Hurley, J., \& Bush, J. (2018). Land-Use Planning's Role in Urban Forest Strategies: Recent Local Government Approaches in Australia. Urban Policy and Research, (0), 1-12. doi: $10.1080 / 08111146.2018 .1518813$

[63] City of Melbourne. (n.d.). Melbourne facts and figures. Retrieved from https://www.melbourne.vic.gov.au/aboutmelbourne/melbourne-profile/Pages/facts-aboutmelbourne.aspx

[64] Australian Bureau of Statistics. (2019, March 27). Regional Population Growth, Victoria, Australia 2017-2018. Retrieved from http://www.abs.gov.au/ausstats/abs/a.nsf/mf/3218.0

[65] Infrastructure Victoria. (2016). Victoria's 30-year infrastructure strategy. Retrieved from http://www.infrastructurevictoria. com.au/project/30-year-strategy/

[66] Department of Planning and Community Development of Victoria State Government. (2008). Victoria's Planning framework for land use and development. Retrieved from hramework for land use and development. Retrieved from https://www.audit.vic.gov.au/sites/defaut//ites/20080507Planning-Framework-for-Land-Use-and-Development.pd
Gulsrud, N. M., Hertzog, K., \& Shears, I. (2018). Innovative urban forestry governance in Melbourne?: Investigating "green placemaking" as a nature-based solution. Environmental Research, (161), 158-167. https://doi.org/10.1016/ i.envres.2017.11.005

[68] Frank, S., Waters, G., Beer, R., \& May, P. (2006). An analysis of the street tree population of greater Melbourne at the beginning of the 21st century. Arboriculture and Urban Forestry, 32(4), 155-163.

[69] City of Moreland. (2017). Urban Forest Strategy 20172027. Retrieved from https://www.moreland.vic.gov.au/ globalassets/key-docs/policy-strategy-plan/urban-foreststrategy-2017.pdf.

[70] Kendal, D., Williams, N. S. G., \& Williams, K. J. H. (2012). Drivers of diversity and tree cover in gardens, parks and streetscapes in an Australian city. Urban Forestry \& Urban Greening, 11(3), 257-265. https://doi.org/10.1016/ i.ufug. 2012.03.005

[71] Dobbs, C., Kendal, D., \& Nitschke, C. (2013). The effects of land tenure and land use on the urban forest structure and composition of Melbourne. Urban Forestry \& Urban Greening 12(4), 417-425. https://doi.org/10.1016/j.ufug.2013.06.006
[72] Kirkpatrick, J. B., Daniels, G. D., \& Davison, A. (2011). Tempor and spatial variation in garden and street trees in six eastern Australian cities. Landscape and Urban Planning, 101(3), 244252. https://doi.org/10.1016/j.landurbplan.2011.02.029

[73] May, P. B., Livesley, S. J., \& Shears, I. (2013). Managing and Monitoring Tree Health and Soil Water Status During Extreme Drought in Melbourne, Victoria. Arboricultutre \& Urban Forestry, 39(3), 136-145.

[74] Bush, J., \& Hes, D. (2018). Urban green space in the transition to the eco-city: Policies, multifunctionality and narrative. In J. Bush \& D. Hes (Eds.), Enabling Eco-Cities (pp. 43-63). Singapore: Palgrave Pivot. https://doi.org/10.1007/978-981-107320-5_4

[75] Kaspar, J., Kendal, D., Sore, R., \& Livesley, S. J. (2017). Random point sampling to detect gain and loss in tree canopy cover in response to urban densification. Urban Forestry \& Urban Greening, (24), 26-34. https://doi. org/10.1016/j.ufug.2017.03.013

[76] Yin, R. K. (2011). Applications of Case Study Research (3rd ed.). Thousand Oaks: Sage Publications Inc.

[77] Glaser, B. G., \& Strauss, A. L. (1967). The discovery of grounded theory: Strategies for qualitative research (1st ed.). Chicago: Aldine Publishing.

[78] Creswell, J. W., \& Creswell, J. D. (2018). Research design: Qualitative, quantitative, and mixed methods approaches (5th ed.J. Thousand Oaks: Sage Publications.

[79] Corbin, J., \& Strauss, A. L. (2014). Basics of qualitative research: Techniques and Procedures for Developing Grounded Theory (4th ed.). Thousand Oaks: Sage Publications.

[80] Boulton, C., Dedekorkut-Howes, A., \& Byrne, J. (2018). Factors shaping urban greenspace provision: A systematic review of the literature. Landscape and Urban Planning, (178), 82-101. https://doi.org/10.1016/j.landurbplan.2018.05.029

[81] Rines, D., Kane, B., Kittredge, D. B., Ryan, H. D. P., \& Butler, B. (2011). Measuring urban forestry performance and demographic associations in Massachusetts, USA. Urban Forestry \& Urban Greening, 10(2), 113-118. https://doi. Forestry \& Urban Greening, $1012 / 1$
org/10.1016/j.ufug.2010.12.005

[82] Young, R. F. (2013). Mainstreaming urban ecosystem services A national survey of municipal foresters. Urban Ecosystem 16(4), 703-722. https://doi.org/10.1007/s11252-013-0287-2

[83] Ordóñez, C., \& Duinker, P. N. (2013). An analysis of urban forest management plans in Canada: Implications for urban forest management. Landscape and Urban Planning, (116), 36-47. https://doi.org/10.1016/j.landurbplan.2013.04.007

[84] Berkes, F., Colding, J., \& Folke, C. (Eds.). (2003). Navigating social-ecological systems: Building resilience for complexity and change. Cambridge: Cambridge University Press.

[85] Berkes, F. (2007). Understanding uncertainty and reducing vulnerability: lessons from resilience thinking. Natural Hazards, 41(2), 283-295. doi:10.1007/s11069-006-9036-7

[86] Kendal, D., \& McDonnell, M. J. (2014). Adapting urban forests to climate change. Citygreen, 1(8), 130. doi:10.3850/ S2010098115000274

[87] Ordónez, C., \& Duinker, P. N. (2014). Assessing the vulnerability of urban forests to climate change. Environmental Reviews, 22(3), 311-321. https://doi.org/10.1139/er-2013-0078

[88] Victoria Planning Authority. (2018). Know your council. Retrieved from https://knowyourcouncil.vic.gov.au/

[89] Hahs, A. K., \& McDonnell, M. J. (2006). Selecting independent measures to quantify Melbourne's urban-rural gradient. Landscape and Urban Planning, 78(4), 435-448. 